\title{
Knowledge management a competitive edge for law firms in Botswana in the changing business environment
}

\author{
Author: \\ Madeleine Fombad ${ }^{1}$ \\ Affiliation: \\ ${ }^{1}$ Department of Information \\ Science, University of \\ South Africa, South Africa \\ Correspondence to: \\ Madeleine Fombad \\ Email: \\ fombamc@unisa.ac.za \\ Postal address: \\ 798 Thomas Avenue, \\ Eastwood, Arcadia 0083, \\ South Africa

\section{Dates:} \\ Received: 12 Aug. 2014 \\ Accepted: 09 June 2015 \\ Published: 31 Aug. 2015 \\ How to cite this article: \\ Fombad, M., 2015, \\ 'Knowledge management \\ a competitive edge for \\ law firms in Botswana in \\ the changing business \\ environment', South African \\ Journal of Information \\ Management 17(1), Art. \\ \#633, 8 pages. http://dx.doi. \\ org/10.4102/sajim.v17i1.633

\section{Copyright:} \\ (C) 2015. The Authors. \\ Licensee: AOSIS \\ OpenJournals. This work is \\ licensed under the Creative \\ Commons Attribution \\ License.
}

Read online:
Background: Law firms in Botswana offer a particularly interesting context to explore the effects of transition in the knowledge economy. Acquiring and leveraging knowledge effectively in law firms through knowledge management can result in competitive advantage; yet the adoption of this approach remains in its infancy.

Objectives: This article investigates the factors that will motivate the adoption of knowledge management in law firms in Botswana, and creates an awareness of the potential benefits of knowledge management in these firms.

Method: The article uses both quantitative and qualitative research methods and the survey research design. A survey was performed on all 115 registered law firms and 217 lawyers in Botswana. Interviews were conducted with selected lawyers for more insight.

Results: Several changes in the legal environment have motivated law firms to adopt knowledge management. Furthermore, lawyers appreciate the potential benefits of knowledge management.

Conclusion: With the rise of the knowledge-based economy, coupled with the pressures faced by the legal industry in recent years, law firms in Botswana can no longer afford to rely on the traditional methods of managing knowledge. Knowledge management will, therefore, enhance the cost effectiveness of these firms. Strategic knowledge management certainly helps to prepare law firms in Botswana to be alive to the fact that the systematic harnessing of legal knowledge is no longer a luxury, but an absolute necessity in the knowledge economy. It will also provide an enabling business environment for private sector development and growth and, therefore, facilitate Botswana's drive towards the knowledge-based economy.

\section{Introduction}

During the last decade of the 20th century, the global economy witnessed an increasing transition from the traditional resources of land, labour, and capital to the knowledge economy, whereby knowledge is considered as a prime input to production, innovation and economic benefits. Botswana is taking positive strides towards becoming a knowledge-based economy (Bwalya 2010; World Bank 2012). Botswana's drive towards transformation to a knowledge-based economy is envisaged in its 'National Vision 2016' (Presidential Task Group 1997), and the President of Botswana's inaugural speech (Office of the President 2010). One of the seven thematic areas of the 'National Vision 2016' envisages that as an educated and informed nation after 50 years of independence, the knowledgebased economy will contribute to an overall objective of transforming the country into a knowledge society, with research and innovation as the cornerstones of development. In this regard, the government has made sustainable investments in physical and technical infrastructure, businesses, education, research and development to facilitate a knowledge intensive economy. The public and private sectors are making concerted efforts to enhance the drive towards the knowledge economy. Law firms in Botswana, therefore, provide an important context in the private sector to explore the effects of transition into the knowledge economy. In the knowledge economy the production and services are based on knowledge-intensive activities that contribute to accelerating the pace of technical and scientific advancement (Powell \& Snellman 2004). Law firms are knowledge-intensive firms, the competitive advantage of which is built on knowledge and how it is used to help clients. A law firm can be described as a business entity that is formed by one or more lawyers to engage in the practice of law and in rendering effective and efficient legal services to clients. Law firms in Botswana are small and they are either sole proprietors or limited liability partnerships. Although the size of these law firms have increased from one to ten lawyers (Fombad 2010; Fombad, Boon \& Bothma 2009) to 21 lawyers from 2014 (Harris 2014), the firm size is considered as small. Concerning the size of firms, Mayer-Schoenberger (1995) observes the following: 
[S]izes of law firms range widely from sole practitioners [lawyers practising alone] to small firms consisting of two to 50 lawyers to midsize firms of 50 to 200 lawyers and to very large professional firms having more than 1000 lawyers. (n.p.)

Lawyers possess professional skills such as legal research, judicial problem-solving and analysis, application of the law to relevant facts, negotiation, drafting, advocacy, interviewing and other general skills such as business management, communication, teamwork, and client relations (Collins 1994; Tjaden 2001).

Although knowledge management has increasingly become a topic of discussion in many competitive law firms (Curve Consulting 2003; Kofoed 2002; Leibowitz 2002; Parson 2002; Rusanow 2003), the empirical studies on the potential benefits and strategic use of knowledge management, amidst the changing legal environment, remain unsung in these firms (Dykema 2014). The studies of Du Plessis $(2004,2011)$ and Du Plessis and Du Toit (2005) on knowledge management in law firms focused on information and knowledge management in support of legal research in a digital environment. Bopape (2010) examines information technology to support knowledge management and Fombad (2010) suggests strategies for knowledge management in law firms in Botswana; whilst Fombad (2014) examines some lessons for knowledge management in small law firms in Botswana. The findings of this article are based on an update of the author's thesis on knowledge management in law firms in Botswana.

\section{Problem statement}

It is becoming apparent that the pressures of the knowledge economy and the changing business environment are compelling law firms to rethink their structures, roles, mission and the manner in which they conduct their business by adopting knowledge management. Nonetheless, strategic knowledge management in law firms in Botswana remains in its initial stages (Fombad 2010, 2014; Fombad et al. 2009). This article identifies factors that will motivate the adoption of knowledge management and the potential benefits for law firms, and will also provide guidelines for strategic knowledge management.

\section{Research objective}

The article seeks to answer the following questions:

- How is the legal information environment changing?

- What factors are motivating the adoption of knowledge management in law firms in Botswana?

- What are the potential benefits of knowledge management in these firms?

\section{Literature review}

This section presents an overview of the concept of knowledge economy, the changes in the legal environment, knowledge management, and the potential benefits of knowledge management to law firms.

\section{The knowledge economy}

There is no universal definition of the knowledge economy. Interrelated concepts such as knowledge society, modern society and network capitalism have been used to describe the term. An understanding of the concept of the information economy is important to appreciate its meaning. The information economy is the period after the industrial age during which economic development depended largely on information and the exploitation thereof, an increase in the use of computers, telecommunication, e-governance, e-commerce, online education and universal access to telephones (Martin 1995). The information economy era was characterised by information-intensive organisations, a significant information sector, the social use of information and learning society (Moore 1999). On the other hand, the term 'knowledge economy' was coined from the report of Organisation for Economic Cooperation and Development (OECD) entitled 'The Knowledge-Based Economy' (1996). According to this report, it is an economy characterised by a hierarchy of networks that is fuelled by the rapid rate of change in all aspects of life, including learning. As a consequence, the OECD obliged all sectors of the economy to respond to the demands of this economy by equipping people with the knowledge and necessary skills to survive in this milieu. Pink (2005) observes that the knowledge economy is built on logical, linear, computer-like capabilities of the information economy where information means wealth and power to an economy in which wealth and power are gained by those who have the cognitive and creative capabilities to reframe information into useful knowledge, although information is freely available. Britz et al. (2006) summarise the distinct characteristics of a knowledge society as:

access to modern ICTs and the use thereof, the number of scientists in a country, the amount spent on research and development as a percentage of the gross domestic product (GDP), the ability to produce and export, high technology, the number of patents filed in a country, and the number of articles published in highly ranked scholarly journals. (n.p.)

Handzic and Zhou (2005) list the characteristics of a knowledge economy as one that is knowledge centric with visible network effects, rapid and unpredicted changes and innovation. The World Bank identifies the four pillars of development in the knowledge economy as education and training, information infrastructure, economic incentive, an institutional regime, and innovative systems (Chen \& Dahlman 2005).

Knowledge economy, therefore, may be referred to as a dematerialised and conceptualised economy driven by affluence and characterised by the use of the following:

- information

- knowledge

- ICTs and distinctive know-how for competitive advantage

- innovation

- learning

- change

- long-term economic growth. 


\section{Changes in the legal information environment}

Traditionally, the practice of law has been built around law books and print technology. Legal research facilities were centred on the paper-based law library, the precedent bank and the collection of press cuttings (Berring 1997; Suender 2013; Wales Library Resources for Lawyers Project Africa 2001). The situation started changing, albeit gradually with the development of online computer-based research systems like LexisNexis and Weslaw in the 1970s (Katsh 1995). Then, the Internet moved the use of ICTs in law firms beyond the automation of existing practices to innovative concepts and applications such as the intranet, Internet deal rooms, extranet, document and content management, online depositions, real time chat, portals, groupware, expert systems and knowledge management systems (Hopkins \& Reynolds 2003; Reach 2006). Nye (1999) predicted that by the year 2025, the Internet would change everything about the practice of law.

As a result of the Internet, the globalisation of business practices has broken down geographical boundaries, leading to an increase in an international collaborative legal practice worldwide (Gottschalk 2014; Wall 1998). Furthermore, there has been an exponential growth in the size of law firms around the world, for example in Botswana the maximum number of lawyers per firm has increased from 11 in 2010 to 21 in 2014. The continuous increase in the number of lawyers and law firms has put pressure on law firms to maintain a competitive edge against one another as far as partners, clients and law graduates are concerned.

The above changes in the legal industry had several consequences, for example information overload has been aggravated. Parson (2002) noted that in the knowledge economy, the explosion of content and the increasing demands for speed in the provision of legal services have ironically led to information anxiety and attention deficit amongst lawyers. Furthermore, clients are becoming computer literate and sophisticated consumers of legal services who expect lawyers to have technologies in place that may enhance their effectiveness (Dubin 2005). In addition, the disintermediation process in law firms has been accelerated (Bradlow 1988; Nye 1999; Susskind 2001). Disintermediation is any activity that does away with an intermediary when rendering services or concluding transactions (Drucker 2000; ESQlawtech 2002). This has given clients the feeling that they are paying for the management skills of lawyers rather than their legal knowledge.

Finally, the competitive business environment has revolutionised the mobility of lawyers. Some are opting for changes to improve on their curriculum vitae and others are in search of greener pastures (Hunter, Beaumont \& Lee 2002). There is, therefore, a growing awareness that if measures are not taken, a vast quantity of vital knowledge and expertise would walk out of the door.

\section{Knowledge and knowledge management}

Knowledge can take on many different forms and has different meanings to each individual organisation. Closely related concepts such as data and information can easily approximate some form of knowledge. Nonaka and Takeuchi (1995) consider knowledge as a true and justified personal belief that increases an individual's capacity to take action. According to Fahey and Prusak (1998), knowledge is what the knower knows that does not exist independently of a knower, but is rather shaped by one's needs and one's initial stock of knowledge. In this article, knowledge is considered as information combined with experience, context, interpretation, reflection, intuition, creativity plus the ability to use the information to act or innovate. It includes truths, beliefs, perspectives, concepts, judgement, expectations, methodologies and the know-how.

Similar to knowledge, there is still no universally accepted definition of knowledge management. From an information technology perspective Platt (2003) defines knowledge management as accessing, evaluating, managing, organising, filtering and distributing information in a manner that would be useful to end users through a technological platform. From an intellectual capital perspective, Smith (2001) considers knowledge management as an on-going procedural 'bottomup' process that develops and exploits the tangible assets and intangible knowledge resources of the organisation and shares it across boundaries in the organisation. From a process perspective knowledge management involves activities such as creation, acquisition, identification, storage, sharing and application of knowledge (Gottschalk 2014).

In this article, strategic knowledge management refers to a set of systematic and disciplined actions an organisation can take to obtain the greatest value from the knowledge available. It is the development of an organisational-wide knowledge management capability designed to provide sustainable competitive advantage (Inelcom \& K-net 2015). It entails establishing a framework that defines the key elements of knowledge management and their interaction with business strategy, organisational design and the business practice (Gottschalk 2014).

\section{Perceived benefits of knowledge management in law firms}

Perceptions of the benefits of knowledge management vary from individual to individual and organisation to organisation. Law firms in Canada, the United States, the United Kingdom and Australia are considering knowledge management as a necessity for meeting emerging client demand for efficiency, accountability, and controlled legal costs (Chester 2002; Nathanson \& Levison 2002). Leading United Kingdom law firms have well-developed precedents and know how systems maintained by fulltime professional support lawyers who are senior lawyers and experts in their field (Kay 2002). Several legal researchers (BecerraFernandez 1999; Curve Consulting 2003; Gottschalk 2014; 
TABLE 1: What would motivate the adoption of knowledge management in your firm? $(N=140)$.

\begin{tabular}{|c|c|c|c|c|c|}
\hline Variable & $\begin{array}{l}1 \text { Strongly } \\
\text { agree in \% }\end{array}$ & $\begin{array}{l}2 \text { Agree } \\
\text { in } \%\end{array}$ & $\begin{array}{l}3 \text { Neutral } \\
\text { in } \%\end{array}$ & $\begin{array}{l}4 \text { Disagree } \\
\text { in } \%\end{array}$ & $\begin{array}{c}5 \text { Strongly } \\
\text { disagree in \% }\end{array}$ \\
\hline Advanced information communication technologies & 74.3 & 23.6 & 2.1 & - & - \\
\hline The shift from paper-based to electronic sources of information & 67.9 & 26.4 & 5.7 & - & - \\
\hline The Internet & $65.7^{\mathrm{a}}$ & $30.0^{\mathrm{a}}$ & $3.6^{\mathrm{a}}$ & $0.7^{\mathrm{a}}$ & - \\
\hline Electronic publishing & 67.1 & 27.9 & - & - & - \\
\hline Globalisation of legal services & $37.1^{\mathrm{a}}$ & $28.6^{\mathrm{a}}$ & $19.3^{\mathrm{a}}$ & $6.4^{\mathrm{a}}$ & $3.6^{\mathrm{a}}$ \\
\hline Competition amongst firms & 33.6 & 36.4 & 25.7 & 4.3 & - \\
\hline Pressure from clients & 20.7 & 34.3 & 29.3 & 15.7 & - \\
\hline Information overload & $17.9^{\mathrm{a}}$ & $23.6^{\mathrm{a}}$ & $32.9^{\mathrm{a}}$ & $15.7^{\mathrm{a}}$ & - \\
\hline Loss of key personnel and their knowledge & 21.4 & 32.9 & 15.7 & 17.9 & 12.1 \\
\hline The use of knowledge management tools and practices by other competitors & 36.4 & 52.1 & 3.6 & 7.9 & - \\
\hline An increase in the mobility of lawyers & 20.7 & 25.7 & 26.4 & 13.6 & 13.6 \\
\hline The need to identify and to protect strategic knowledge in the firm & 50.0 & 33.6 & 8.6 & 6.4 & 1.4 \\
\hline The desire to promote professional satisfaction & 65.0 & 29.3 & 5.7 & - & - \\
\hline The desire to promote teamwork & 65.0 & 25.7 & 9.3 & - & - \\
\hline The desire to meet the information and knowledge needs of the lawyer & 65.7 & 30.0 & 4.3 & - & - \\
\hline Pressure from other professional service firms & 25.7 & 27.9 & 27.1 & 14. 3 & 5.0 \\
\hline
\end{tabular}

a, Percentages that do not add up as a result of non-response.

Kay 2002; Leibowitz 2004; Opp 2004; Whitfield-Jones 1999) have noted that the successful implementation of knowledge management strategy in law firms may result in the following benefits:

- Innovation is sustained and the free flow of ideas is encouraged.

- Learning is enhanced as well as the ability to stay ahead of competition and changes in the legal information environment.

- The quality of knowledge work is improved.

- Individual and group competencies are enhanced.

- It provides opportunities for more effective networking and collaboration.

- Customer service is maintained by streamlining response times.

- Revenue is boosted with the faster arrival of products and services to market.

- Redundancy is eliminated and employee retention rates are enhanced by recognising the value of employees' knowledge and rewarding them for it.

- Operations are streamlined and costs reduced by eliminating redundant or unnecessary processes.

\section{Research methodology}

A qualitative and quantitative research method was adopted and open and closed-ended questionnaires and semistructured interviews were used as instruments. A survey research design was used. The target population was the sampling frame requested and obtained from the Botswana Law Society which consists of a list of registered private law firms; these firms comprised 115 registered law firms in Botswana and a total of 217 lawyers. A census of the total population of 217 was adopted for the questionnaire survey. Interviews were held to complement the census. The researcher adopted the purposive sampling technique and limited the interviews to law firms in Gaborone. Gaborone was deliberately chosen to administer the interviews, because of its accessibility and proximity and the majority of the lawyers are based in Gaborone. In order to validate the instrument, preliminary interviews were conducted with lawyers. The questionnaire was then critically reviewed to ensure that there is some similarity between the interview questions and those in the questionnaire. The questionnaire was modified and the feedback and suggestions from the promoter taking into account, and the opinions of experts in knowledge management research were sought to evaluate the instrument with regard to comments on language and structure. The Statistical Package for Social Scientists (SPSS) version 15.0 was used for the analysis of the data collected from the close-ended questionnaires. On the other hand, qualitative data were derived from the open-ended questions and the interviews conducted, with 15 lawyers who had been selected from different law firms in Gaborone, were coded using thematic content analyses. About 140 completed questionnaires were returned, which translated to a return rate of $64.5 \%$. The participants were asked to rate the questions on a five point scale of 'strongly agree', 'agree', 'neutral', 'disagree' and 'strongly disagree'.

\section{Data analysis and findings}

The frequency distribution of participants, concerning their level of education, revealed that a majority, 116 (83\%) have bachelor's degrees and $24(17.1 \%)$ have Master's degrees. Furthermore, amongst other qualifications were executive masters in sports organisations, a post graduate diploma in international law, and a diploma in trial advocacy. With regard to longevity of practice, the length of practice of participants ranges from 1-33 years. The mean number of years of practice is 6 years. With regard to organisational characteristics the following demographics are found:

- 55 participants (39.3\%) are sole proprietors

- $49(35.0 \%)$ have 2 lawyers

- $23(16.4 \%)$ have 3 lawyers

- $11(7.9 \%)$ have 4 lawyers

- $1(0.7 \%)$ has 5 lawyers

- $1(0.7 \%)$ has nine lawyers. 
TABLE 2: The perceived benefits of knowledge management in law firms in Botswana $(N=140)$.

\begin{tabular}{|c|c|c|c|c|c|}
\hline Variable & $\begin{array}{l}1 \text { Strongly } \\
\text { agree in \% }\end{array}$ & $\begin{array}{l}2 \text { Agree } \\
\text { in \% }\end{array}$ & $\begin{array}{l}3 \text { Neutral } \\
\text { in } \%\end{array}$ & $\begin{array}{l}4 \text { Disagree } \\
\text { in } \%\end{array}$ & $\begin{array}{c}5 \text { Strongly } \\
\text { disagree in \% }\end{array}$ \\
\hline Improve knowledge sharing & 60.7 & 39.3 & - & - & - \\
\hline Improve lawyers efficiency and productivity & 63.6 & 31.4 & 5.0 & - & - \\
\hline Improve lawyers' relationship vis-à-vis clients and customers & 57.1 & 27.9 & 15.0 & - & - \\
\hline Prevent duplication in research & 60.0 & 31.4 & 8.6 & - & - \\
\hline Increase flexibility amongst lawyers & 51.4 & 35.7 & 7.1 & 5.7 & - \\
\hline Increase flexibility amongst lawyers & 51.4 & 35.7 & 7.1 & 5.7 & - \\
\hline Protect the firm's loss of knowledge & 70.0 & 22.9 & 7.1 & - & - \\
\hline Result in competitive advantage & 52.9 & 26.4 & 20.7 & - & - \\
\hline Integrate knowledge within the firm & 60.7 & 31.4 & 6.4 & - & 1.4 \\
\hline Improve retention rate of lawyers in the firm & 46.4 & 28.6 & 20. & 50 & - \\
\hline Improve the sharing and transfer of knowledge with partners and strategic alliances & 58.6 & 31.4 & 10.0 & - & - \\
\hline Enhance economic profitability & 60.7 & 29.3 & 10.0 & - & - \\
\hline
\end{tabular}

It also emerged from the interviews that the law firms in Botswana remain small with an average of two partners due to the fact that every lawyer wants to become a partner rather than just working as a professional assistant, because partners receive a share of the profit. As a result lawyers constantly leave law firms to start off as sole proprietors or to form small partnerships.

\section{Factors that motivate the adoption of knowledge management in a law firms}

Against the background of some of the changes in the legal information environment, this question listed the possible factors that may motivate a firm to adopt knowledge management (Table 1).

In general the responses show that lawyers acknowledged the need for knowledge management in their firms. They acknowledged that the following have triggered the adoption of knowledge management:

- advances in information communication technology $(97.9 \%)$

- the Internet $(95.7 \%)$

- electronic publishing $(95.0 \%)$

- the shift from paper-based to electronic sources (94.3\%).

The following are some responses from interviewees about the reasons for adopting knowledge management:

- Lawyers do not stay in one firm; they are moving from firm to firm.

- Lawyers are constantly splitting up in the law firms to start off as sole proprietors or to form partnerships.

- We are under pressure to attract new clientele.

- It will be good to network with other lawyers.

- If only knowledge can be standardised.

- There is a lot of competition out there as to who owns the best knowledge.

- We have to keep up with the changes around us in the international law firms.

- The Internet, computers, observation from other lawyers and networking with other lawyers are a challenge to our firm.

\section{The perceived benefits of knowledge management for the law firms}

Various items on perceived benefits of knowledge management are presented in Table 2.

The findings revealed that participants generally recognised the potential benefits of knowledge management. They all agreed $(100 \%)$ that a good knowledge management attitude would improve knowledge sharing in the firm. Knowledge management attitude is generally reflected in the way a firm accesses and shares its knowledge communication style, trust and teamwork (Forstenlechner 2006; Lambe 2003; Rusanow 2007). These findings contradict the general notion that law firms are noted for their expertise, and secretive, individualistic culture (Lambe 2003; Maiden 2002; Terrett 1998:68). Lawyers further acknowledged that knowledge management would prevent duplication in research, of whom $91.4 \%$ agreed. The participants agreed that knowledge management would protect law firms from losing knowledge $(92.9 \%)$, it would improve the retention rate of lawyers (75.0\%) and integrate knowledge within the firm (92.1\%). Many lawyers recognised that knowledge management would improve lawyers' relationships with their clients $(85.0 \%)$. It, therefore, seems that lawyers appreciate the benefits of improving their relationship with their clients (Lim \& Klobas 2000). The participants also acknowledged that knowledge management would improve the lawyer's efficiency, productivity $(95.0 \%)$, and flexibility $(87.1 \%)$. It is likely that improvement in efficiency and productivity will enhance a lawyer's flexibility, thus resulting in professional satisfaction. These findings confirm the research that knowledge management would expose lawyers with special experience and expertise to work on projects in their area to such an extent that they attain professional excellence, equip themselves with advanced skills and provide exceptional services to clients (Chester 2002; Rodriguez, Garcia \& Pizarro 2002; Rusanow 2003, 2007; Wesemann 2006). Timely billing, the ability to respond to the unexpected, the ability to create innovative solutions for blue sky thinking, and the ability to curb legal costs are likely to benefit the client. Law firms in Canada, the United States, the United Kingdom and Australia are considering knowledge management as a 
necessity for meeting emerging client demand for efficiency, accountability, and controlled legal cost (Chester 2002; Nathanson \& Levison 2002; Rusanow 2007; Wesemann 2006).

Most of the participants agreed that knowledge management would enhance economic profitability $(90.0 \%)$. As a result of the delivery of high quality legal services to satisfied clients, more business will be generated which will result in better economic performance and knowledge management results in the fast delivery of high quality services.

Respondents also agreed that knowledge management will improve the retention rate $(75 \%)$. Knowledge management initiatives enable firms to attract and retain talented lawyers and also their clients. In situations where lawyers decide to leave the firm, knowledge management provides for a continuity of knowledge. It also helps to capture and effortlessly share senior lawyers' knowledge in the firm. Responses from the 'other' category and the interviews indicated that the perceived benefits of knowledge management in law firms would result in general efficiency, improvement of quality of output, and improvement of the quality of the clients. The following are notable responses from the interviews in this study, with regard to the perceived benefits of knowledge management in law firms in Botswana:

- It is encouraging to know that I can always get what I need within the time frame available for it because currently I spend a lot of time sort of reinventing the wheel.

- It seems to be the trend and an essential function in today's law firm environment.

- As a fairly young legal practitioner, it is heartening to know that with knowledge management in place, there will be somewhere to inquire information about what you do not know because it is presently difficult working without any prior experience and with no one willing to assist you.

- I appreciate its potential to improve the overall efficiency of the firm.

- The thought that it will make my work easy.

- It will improve the quality of clients.

- It will provide the ability to network with other lawyers within and out of the country.

Although lawyers seemingly recognise the potential benefits of knowledge management, these promised benefits remain around the corner because the adoption of knowledge management still remains in its infancy.

\section{Limitations}

A major limitation of this paper is that the findings specifically apply to law firms and, therefore, insights into other branches of the legal profession may be lacking that fall under the Judicial Service Commission (e.g. judges, magistrates and court registrars), legal practitioners in the Attorney General's Chambers and, legal academics. Furthermore, it does not examine other professional service firms that render professional services. Although it is believed that these findings could apply to other branches and professional service firms. Future studies should investigate knowledge management as a competitive edge in the legal profession and in other firms in Botswana that render professional services.

\section{Conclusion and recommendations}

This article paints a picture of a profession that is aware of the enormous potential benefits of knowledge management amidst the changes in the legal environment, although the adoption of knowledge management is still in its infancy. In order for law firms in Botswana to sharpen their competitiveness, broaden their influence, and survive in a legal environment characterised by aggressive changes, the approach to knowledge management should be strategically thought out. Centaur Media (2014) posits that knowledge management discourse in law firms has moved from creating and managing internal documents to creating value for the client. On the other hand Winston (2014) argues that knowledge management in law firms has shifted beyond the provision of legal services, to supporting and integrating expanding law firms to cope with information overload, and is now focused on helping attorneys do more with less. It, therefore, stands to reason that strategic knowledge management will entail that law firms in Botswana leverage their knowledge for competitive advantage, build up market trends, and develop business strategies directed at meeting the needs of clients and other lawyers. In rethinking the knowledge management approach in these firms, an understanding and sensitivity to the size, ideals and characteristics of these firms is crucial given that they are predominantly small firms (Fombad 2014). Knowledge management in these firms should be simple and implemented at a rate which is commensurate with their level of resources. Also, issues of cultural resistance are critical (Zeide \& Liebowitz 2012). To this end, law firms should create an environment where knowledge, creativity and innovation are valued by facilitating communication amongst people in different locations and from different departments. Law firms should encourage ideas, rewards and success, whilst allowing people to fail and learn from their failures.

Therefore, with the rise of the knowledge-based economy, coupled with the pressures faced by the legal industry in recent years, law firms in Botswana can no longer afford to rely on the traditional methods of managing knowledge, because they need the 'best minds' and the best knowledge in their area of practice. Knowledge management will, therefore, enhance the cost effectiveness of these firms. Although knowledge management is not a quick fix or ready-made panacea, it will certainly help prepare law firms in Botswana to be alive to the fact that the systematic harnessing of legal knowledge is no longer a luxury, but an absolute necessity in the knowledge economy above all, it will provide an enabling business environment to private sector development and growth and, therefore, facilitate 
Botswana's drive towards the knowledge-based economy as envisaged in its National Vision 2016.

\section{Acknowledgements Competing interests}

The author declares that she has no financial or personal relationships which may have inappropriately influenced her in writing this article.

\section{References}

Becerra-Fernandez, I., 1999, 'Knowledge management today: Changing the corporate culture', in Proceedings of the 5th International Conference of Decision Science Institute, July 4-7.

Berring, R., 1997, 'Chaos, cyberspace and tradition: Legal information transmogrified', viewed 04 May 2014, from http://www.law.berkly/edu/journals

Bopape, S., 2010, 'Utilisation of information technology to support information and Knowledge management by lawyers in Polokwane City', South African Journal of Library and Information Services 76(2), 129-140.

Bradlow, D., 1988, 'The changing legal environment 1980 s and beyond', ABA Journal 1, 72-76.

Britz, J., Lor, P., Coetzee, I. \& Bester, B., 2006, 'Africa as a knowledge society: A reality check', The International Information \& Library Review 38, 25-40. http://dx.doi. org/10.1016/j.iilr.2005.12.001

Bwalya, K.J., 2010, 'Botswana's novel approaches for knowledge-based economy facilitation: Issues, policies and contextual framework', International Journal of Information Communication Technologies and Human Development 2(1), 59-74. $\mathrm{http}: / / \mathrm{dx}$.doi.org/10.4018/jicthd.2010010104

Centaur Media, 2014, 'How helpful is your KM?', Lawyer (Online Edition) 9(25).

Chen, D.C. \& Dahlman, C.J., 2005, 'The knowledge economy, the KAM methodology and World Bank operations', viewed 17 February 2014, from http://siteresources. worldbank.org

Chester, S., 2002, 'Knowledge management in Canadian law firms', Pacific Legal Technology Conference Vancouver Trade and Technology Centre', viewed 07 June 2014, from www.lawsociety.bc.ca

Collins, H., 1994, 'The place of computer in legal education', Law Technology Journa 3(3), viewed 08 August 2014, from http://www.law.warwick.ac

Curve Consulting, 2003, 'Global law firm knowledge management survey report', viewed 09 February 2012, from http://www.curveconsulting.com/ pages/

Drucker, P., 2000. 'The new economy and the virtual law firm of the future', viewed 25 August 2012, from http://www.digitallawyer.com/virtual2.html

Du Plessis, T., 2004, 'Information and knowledge management in support of legal research in a digital environment', PhD thesis, Faculty of Arts, University of Rand Afrikaans.

Du Plessis, T., 2011, 'Information and knowledge management at South African law firms', Potchefstroom Electronic Law Journal 14(4), 233-258. http://dx.doi. org $/ 10.4314 /$ pelj.v14i4.8

Dubin, M., 2005, 'Creating an environment in the law firms where knowledge management will work', viewed 12 January 2013, from http://www. searchwarp.com

Du Plessis, T. \& du Toit, A., 2005, 'Survey of information and knowledge management in South African law firms', South African Journal of Information Management 7(1). http://dx.doi.org/10.4102/sajim.v7i1.252

Dykema, E., 2014, 'Knowledge management: Law firm reluctant to reap the rewards', viewed 10 February 2015, from https://caserails.com/blog/knowledgemanagement-law-firms-reluctant-reap-rewards

ESQlawtech, Ltd., 2002, 'Law office technology transforming the legal profession. The Esqlawtech weekly', viewed 09 June 2012, from http://www.mylawtips.com/ officetechnology.html

Fahey, L. \& Prusak, L., 1998, 'The Eleven deadliest sins of knowledge management', California Management Review 40(3), 265-276. http://dx.doi. org/10.2307/41165954

Fombad, M., 2010, 'Strategies for knowledge management in law firms in Botswana', Ph.D., Dept. of Information Science, University of Pretoria, Pretoria.

Fombad, M., 2014, 'Knowledge management in law firms in Botswana: Some lessons for small law firms', Journal of Librarianship and Information Science, viewed 30 May 2014, from http://lis.sagepub.com/content/ early/2014/05/28/09610006145364

Fombad, M., Boon, J.A. \& Bothma, T.J.D., 2009, 'Strategy for knowledge management in law firms in Botswana', South African Journal of Information Management 11(2). http://dx.doi.org/10.4102/sajim.v11i2.405

Forstenlechner, I., 2006, 'Impact of knowledge management on law firm performance: An investigation of causality across cultures', PhD Thesis, School of Industrial and Manufacturing Science, Cranfield University.

Gottschalk, P., 2014, 'Knowledge management strategy in professional service firms', Advances in Management 7(3), 16-22.
Handzic, M. \& Zhou, A.Z., 2005, 'Knowledge management: An integrative approach' Chandos Publishing, Oxford. http://dx.doi.org/10.1142/5639

Harris, J., 2014, 'Neighbourhood watch', Lawyer 28, 14(3), 16-16

Hopkins, R. \& Reynolds, P., 2003, 'Redefining privacy and security in the electronic communication age: A lawyers ethical duties in the virtual world of the internet', The Georgetown Journal of Legal Ethics 16(4), 675-684.

Hunter, L., Beaumont, P. \& Lee, M., 2002, 'Knowledge management practice in Scottish law firms', Human Resource Management Journal 12(2), 4-21. http:// dx.doi.org/10.1111/j.1748-8583.2002.tb00061.x

Inelcom \& K-net, 2015, 'Strategic knowledge management \& knowledge', viewed 08 February 2015, from http://www.kbos.net/default.aspx?articlelD=10315

Katsh, M., 1995, 'Law in the digital world', viewed 08 May 2013, from http://www. umassp.edu/legal/dw control.html

Kay, S., 2002, 'Benchmarking knowledge management in U.S. and U.K law firms', viewed 11 October 2012, from http://www.llrx.com/features/bench markingkm. html

Kofoed, K., 2002, 'Knowledge management in law firms', MBA Cambridge Business School, University of Cambridge, Cambridge.

Lambe, P., 2003, 'What does knowledge management mean for the law firms', viewed 11 September 2014, from http://www.greenchameleon.com

Leibowitz, W., 2002, 'Knowledge management in the law firm. Wendy Tech Articles', viewed 09 September 2013, from http://www.WendyTech.com

Leibowitz, W., 2004, 'Knowledge management in the law firm. Wendy Tech Articles', viewed 09 September 2013, from http://www.WendyTech.com

Lim, D. \& Klobas, J., 2000, 'Knowledge management in small enterprises', The Electronic Library 18(6), 420-433. http://dx.doi.org/10.1108/02640470010361178

Maiden, C., 2002, 'The secret life if lawyers reinventing law', viewed 15 January 2013 , from http:// www.ask.bm

Moore, N.I., 1999, 'Partners in the information Society', Library Association Record, 101(12), 702-703.

Martin, W.J., 1995, The Global Information Society, Aslib Gower.

Mayer-Schoenberger, V., 1995, 'Lawyering on the Infohbahn: The European perspective', Law Technology Journal June 4(1), 5-95.

Nathanson, A. \& Levison, A., 2002, 'Differentiate your firm with knowledge management', Legal Information Technology, viewed 5 November 2012, from http://www.brco.com/downloads/articles/

Nonaka, I. \& Takeuchi, H., 1995, The knowledge creating company, University Press, Oxford.

Nye, A., 1999, 'The lawyer of the future', Maine Lawyer's Review 7(12).

Organisation for Economic Cooperation and Development (OECD), 1996, 'The Knowledge-Based Economy', viewed 20 February 2014, from http://www.oecd. org/sti/sci-tech/1913021.pdf

Office of the President, 2010, 'Report on public service customer satisfaction and staff perception surveys', prepared by Economic and Management Consultants. Unpublished.

Opp, K., 2004, 'Commentary: The importance of knowledge management to a firm', viewed 05 May 2013, from http://www.accessmylibrary.com

Parson, M., 2002, 'Uncommon knowledge: The Knowledge management questions for service firms', Professional Review 11, 2-3.

Pink, D.H., 2005, 'A whole new mind: moving from the information age to the conceptual age', Penguin, New York.

Platt, N., 2003, 'Knowledge is power: knowledge management remains vital to the firm's success AALL Spectrum', viewed 05 August 2013 from, http://www.llrxcom/ features/kmpower.html

Powell, W. \& Snellman, K., 2004, 'Thee knowledge economy', Annual Review of Sociology 30, 199-220. http://dx.doi.org/10.1146/annurev.soc.29.010202. Sociology
100037

Presidential Task Group, 1997, Long-term Vision for Botswana: Towards Prosperity for All, Government Printer, Gaborone.

Reach, C., 2006, Positioning for power: Technology and the law firm librarian, American Bar Association, viewed 11 June 2012, from http://www.abanet.orgpower.htm

Rodriquez, C., Garcia, J. \& Pizarro, J., 2002, 'Knowledge management in law firm', Upgrade 3(1), 51-54.

Rusanow, G., 2003, Knowledge management is a business imperative, viewed 03 August 2013, from http://www.llrx.com

Rusanow, G., 2007, 'Combining business and practice knowledge management and the law', Knowledge Management World 16(1), 12-15.

Smith, E., 2001, 'The role of tacit and explicit knowledge in the workplace', Journal of Knowledge Management 5(4), 311-321. http://dx.doi.org/10.1108/ 13673270110411733

Suender, M., 2013, 'Alternatives to the partnership track', Law Practice: The Business of Practicing Law 39(3), 40-43.

Susskind, R., 2001, 'The changing face of private law practice: Part 111. Working notes on deliberations of the committee on research about the future of the legal profession on the current status of the legal profession', viewed 10 September 2012, from http://www.abanet.org

Terret, A., 1998, 'Knowledge management and the law firm', Journal of Knowledge Management 2(1), 67-76. http://dx.doi.org/10.1108/EUM0000000004608 
Tjaden, T., 2001, Legal research and writing: Law in a nutshell, Irwin Law, Toronto.

Wales Library Resources for Lawyers Project Africa, 2001, 'The Bar Human Rights Committee of England and Wales and-The British Council', viewed 10 February 2015, from www.barhumanrights.org.uk/sites/default/files/.../uganda_report.do

Wall, D., 1998, 'Information technology and the shaping of legal practice in the UK', paper presented at the 13th BILETA conference, 27-28 March, viewed 16 December 2012, from http://www.bileta.ac.uk

Wesemann, P., 2006, 'Knowledge management: Is the emperor wearing clothes. Edge International', viewed December 2013, from http://www.edge.ai/Edge International.
Whitfield-Jones, C., 1999, Business as usual or the end of as we know it, Managing Partner, London.

Winston, A.M., 2014, 'Law firm knowledge management: A selected annotated bibliography', Law Library Journal 2(10), 106.

World Bank, 2012, 'Knowledge economy index, moving towards the knowledge economy', viewed 12 February 2015, from http://botswana.opendataforafrica. org/WBKEI2013/knowledge-economy-index-world-bank-2012

Zeide, E. \& Liebowitz, J., 2012, 'Knowledge management in law: A look at cultural resistance', Legal Information Management 12(1), 34-38. http://dx.doi. org/10.1017/S1472669612000126 